\title{
Understanding the diversity of values of "Nature's contributions to people": insights from the IPBES Assessment of Europe and Central Asia
}

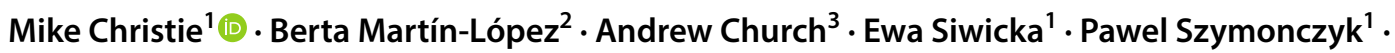 \\ Jasmin Mena Sauterel ${ }^{2}$
}

Received: 17 August 2018 / Accepted: 2 July 2019 / Published online: 17 July 2019

(c) The Author(s) 2019

\begin{abstract}
Assessments of the value of nature (e.g., TEEB. The economics of ecosystems and biodiversity: ecological and economic foundations, London, 2010) have tended to focus on the instrumental values of ecosystem services. However, recent academic and policy debate have highlighted a wider range of values (e.g., relational and intrinsic values), valuation methods (e.g., socio-cultural methods), and worldviews [e.g., indigenous and local knowledge (ILK) systems]. To account for these new perspectives, the Intergovernmental Science-Policy Platform for Biodiversity and Ecosystem Services (IPBES) has developed the concept of 'Nature's contributions to people' (NCP), which aims to be a more inclusive approach to understanding and accounting for the diversity of values held by different stakeholders. In this paper, we aim to critically appraise the merits of the IPBES conceptual framework by reviewing of the findings the IPBES Europe and Central Asia (ECA) assessment. Our objectives are: (1) To review and assess the instrumental and relational values of NCP in Europe and Central Asia? (2) To consider what additional insights into the value of NCP are gained through the inclusion of socio-cultural valuations and ILK? Our analysis demonstrates that the ECA assessment captures a wide range of instrumental and relational values of NCP; however, we acknowledge variation in the availability of this value evidence. We also highlight new insights that can be uncovered through the adoptions of socio-cultural valuation methods and analysis of ILK knowledge. We conclude that the NCP paradigm, with its focus on instrumental and relational values, treats values more holistically than previous assessments such as TEEB (2010). For example, by giving a 'voice' to ILK holders, we demonstrated new types of NCP such as carrion removal, along with evidence of relational values including sense of place, identity, symbolic values and sacredness. While the ECA assessments may be defined as an example of a 'Multiple evidence base' approach to valuation of ecosystem assessments, the ECA assessment fails to demonstrate how to incorporate this wider range of values in decision-making processes.
\end{abstract}

Keywords IPBES $\cdot$ Nature's contribution to people $\cdot$ NCP $\cdot$ Nature $\cdot$ Ecosystem services $\cdot$ Valuation $\cdot$ Value

\section{Introduction}

Handled by Christopher M. Raymond, Helsinki Institute of Sustainability Science, University of Helsinki, Finland.

Electronic supplementary material The online version of this article (https://doi.org/10.1007/s11625-019-00716-6) contains supplementary material, which is available to authorized users.

Mike Christie

mec@aber.ac.uk

1 Aberystwyth Business School, Aberystwyth University, Aberystwyth, Wales SY23 3DY, UK
Over the past few decades, there has been a growing academic and policy interest in assessing the environmental, economic, and social impacts of biodiversity loss and ecosystem degradation. In particular, the ecosystem services framework has been advocated as a useful tool that provides

2 Faculty of Sustainability, Institute for Ethics and Transdisciplinary Sustainability Research, Leuphana University, Lüneburg, Germany

3 University of Brighton, Brighton, UK 
a holistic and transparent assessment of these impacts on human well-being (IPBES 2018c). Global assessments have been a key driver in the development of this conceptual framework. The Millennium Ecosystem Assessment (MEA) (2005) was instrumental in developing and promoting ecosystem services research. However, the MEA stopped short of assessing the economic values of these services. The Economics of Ecosystems and Biodiversity (TEEB) (2010) report aimed to fill this knowledge gap through a meta-analysis of existing economic (monetary) evidence on the instrumental values of ecosystem services across the different global biomes (de Groot et al. 2012).

Since TEEB (2010), a wider academic and policy debate has been developing concerning how to move beyond a focus on economic values to one that also examines more diverse conceptualisations of values, valuation, and worldviews (Kenter et al. 2015; Costanza et al. 2017; Arias-Arevalo et al. 2018; Braat 2018). This debate has also raised concerns that the ecosystem services framework predominantly focuses on the western, scientific concepts of ecosystem services, and as such often fails to account for the preferences and values associated with indigenous and local knowledge (ILK) systems (Díaz et al. 2018; Kirchhoff 2019). In developing its conceptual framework, the Intergovernmental SciencePolicy Platform for Biodiversity and Ecosystem Services' (IPBES) aimed to account for these concerns.

IPBES was established in 2012 to 'strengthen the sciencepolicy interface for biodiversity and ecosystem services for the conservation and sustainable use of biodiversity, longterm human well-being and sustainable development' (https ://www.ipbes.net/). In its conceptual framework (Fig. 1), IPBES explicitly acknowledges the wider conceptualizations of values and valuation (Pascual et al. 2017; Diaz et al. 2018; IPBES 2018c). To reflect these advancements, the IPBES conceptual framework coined the notion of "Nature's contributions to people" (NCP) (Fig. 1). NCP may be assessed from two complementary perspectives (Diaz et al. 2015). First, the generalizing perspective includes $17 \mathrm{NCP}$, organized into three groups (Fig. 2): regulating, material and nonmaterial contributions [which largely map onto the MEA (2005) regulating, provisioning and cultural services]. Importantly, the IPBES framework shows NCP as overlapping between groups, reflecting the observation that there is often fluidity within NCP, e.g., wild food gathering could be considered as both material and non-material NCP. The second, context-specific perspective includes cultural aspects of ILK and can reflect more holistic conceptualizations of human-nature relationships (Diaz et al. 2015).

In relation to how values are expressed in the IPBES conceptual framework (Fig. 2), NCP are considered to enhance people's Quality of life in terms of:
- Instrumental values These values are often expressed within a total economic value framing and can be classified into (direct and indirect) use values and non-use values (option, bequest, and existence values) (IPBES 2018c).

- Relational values The values that contribute to desirable relationships, such as those among people and between people and nature, as in "living in harmony with nature" (Chan et al. 2016; IPBES 2018c).

The IPBES conceptual framework also acknowledges intrinsic values as the value inherent to nature, independent of human experience and evaluation (IPBES 2018c).

Jacobs et al. (2018) found that economic (monetary) valuation techniques predominantly conceive of values as solely instrumental values, whereas socio-cultural valuation techniques consider values as either instrumental (Raymond et al. 2014), relational, or both (Jacobs et al. 2018). Economic valuation techniques tend to express instrumental value of NCP through monetary indicators, elicited using market-based approaches (e.g., market pricing) and non-market monetary approaches (e.g., travel cost method, hedonic pricing, or stated preference methods) (Christie et al. 2012; Jacobs et al. 2018). Socio-cultural valuation techniques tend to elicit values through nonmonetary indicators, such as preferences, narratives, or time (Jacobs et al. 2016). While monetary valuation is often framed in the so-called total economic value framework (Pearce and Moran 1994), socio-cultural valuation draws on a wider range of disciplines to examine the importance, preferences or needs expressed by people towards nature (Chan et al. 2012). Since intrinsic values are beyond the scope of anthropocentric valuation approaches (IPBES 2015), we do not consider intrinsic values further in this research.

The IPBES conceptual framework thus aims to draw on recent advances in valuation research to extend, through the conceptualisations of NCP, the integration of diverse values and ILK systems, to show the multiple ways nature contributes to human well-being (Gomez-Baggethun and Martin-Lopez 2015). From a theoretical viewpoint, it could be argued that IPBES aspires to take a 'pragmatism' perspective (Moon and Blackman 2014) by embracing different disciplines and knowledge systems in the co-construction of evidence on the state of the world's biodiversity and the benefits it provides to people (Diaz et al. 2015). However, IPBES does not explicitly set out a single theoretical position to be adopted in ecosystem service assessments. Instead, the IPBES approach for undertaking ecosytem service assessments (IPBES 2015) reflect the multiple evidence base perspective (MEB) (Tengö et al. 2014), in that it seeks to collate knowledge from multiple evidence sources including scientific data and ILK (e.g., Hill et al. 2019). The MEB approach 


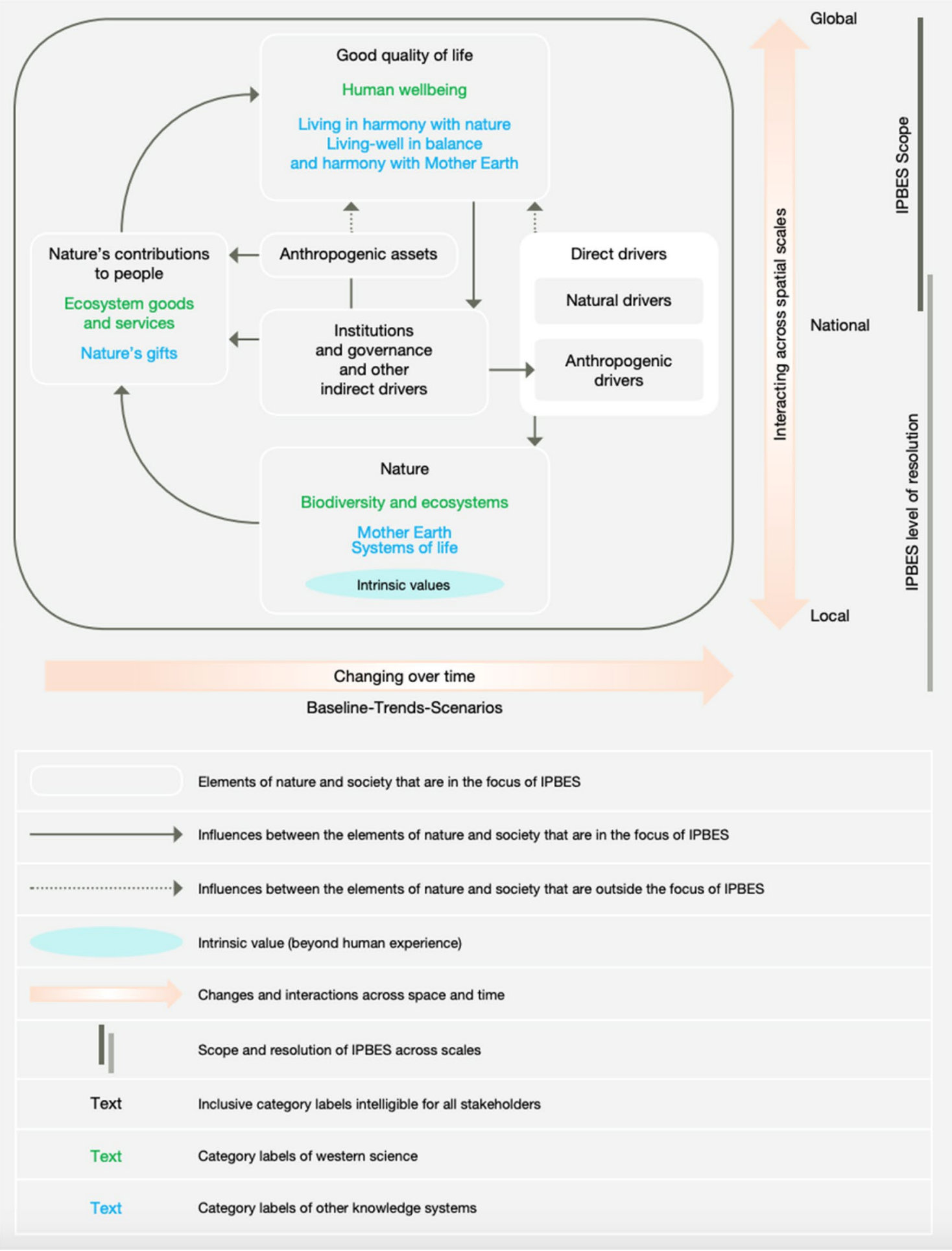

Fig. 1 IPBES conceptual framework Source: Díaz et al. (2018) and (IPBES 2018c)

then argues that discussion among all actors involved generate an enhanced understanding of the environmental conditions, which in turn can help identify sustainable management options (Tengö et al. 2014). Based on Barton et al. (2018) typology of decision maker's requirements, the purpose of the ECA assessment is thus explorative in terms of conducting research aimed at developing science theory and concepts and informative in terms of collating information on, and raising awareness of, the current state, and trends of NCP values in Europe and Central Asia. The ECA 


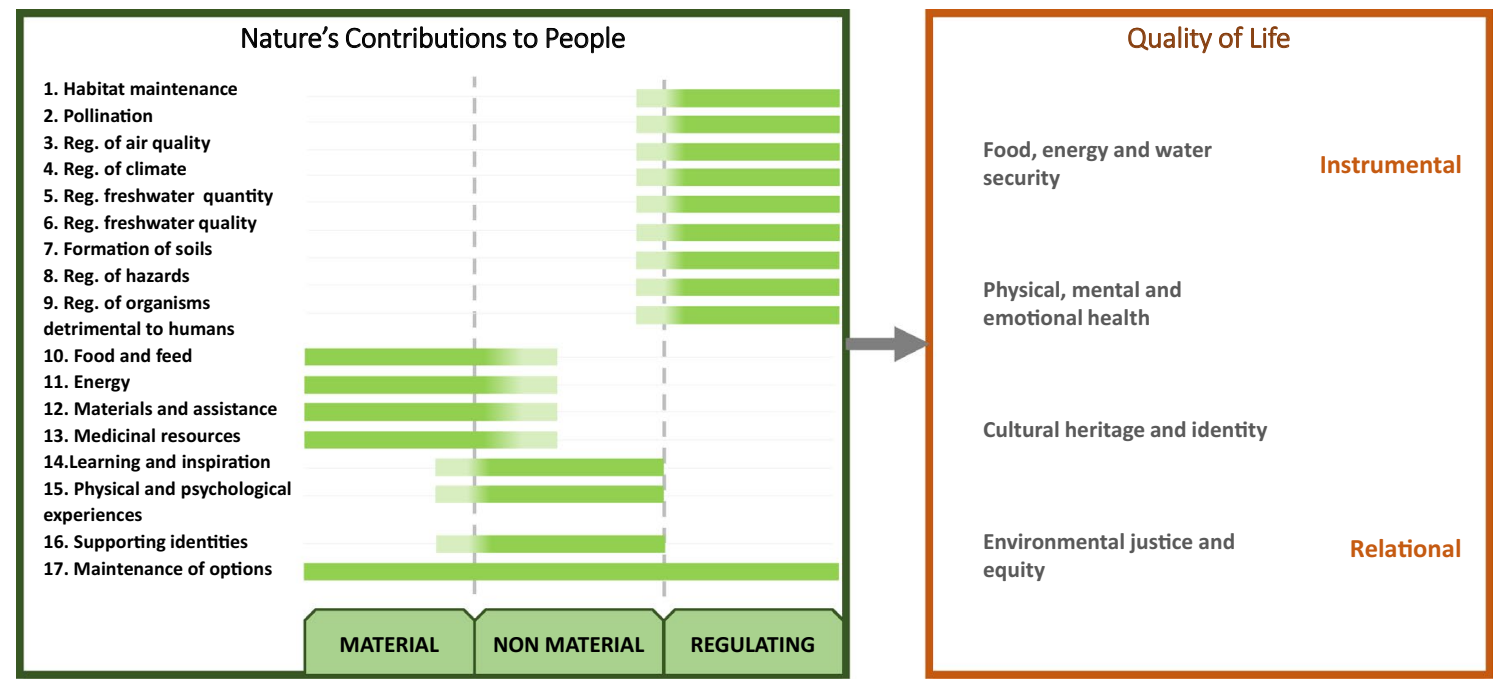

Fig. 2 Nature's contributions to people (NCP) and their relation to quality of life in terms of instrumental and relational values. Most NCP straddle across the categories of material, non-material and regulating NCP. Figure adapted from Díaz et al. (2018) and (IPBES 2018c)

assessment, however, feeds into IPBES, which over time also aims to be decisive in terms of generating actions on specific decision problems, and design through the design and implementation of policy instruments to produce outcomes.

In this paper, we aim to critically appraise the merits of the IPBES conceptual framework as an inclusive approach to capturing the diversity of values associated with NCP. Specifically, we draw on the findings the IPBES Europe and Central Asia (ECA) assessment (IPBES 2018c; Martín-López et al. 2018), which is one of the first large scale, regional assessments that have adopted the IPBES conceptual model. To address our research aim, we consider the following research objectives.

(1) To review and assess the instrumental and relational values of NCP in Europe and Central Asia.

(2) To consider what additional insights into the value of $\mathrm{NCP}$ are gained through the inclusion of socio-cultural valuations and ILK.

We acknowledge that there has been considerable debate of the IPBES approach, with critics questioning whether the adoption of the NCP terminology is useful in terms of effectively embracing a wider conceptualisation of values than is currently incorporated within the concept of ecosystem services (de Groot et al. 2018; Kenter 2018; Maes et al. 2018). Their arguments being that ecosystem service research is already considering a wider conceptualisation of value beyond instrumental values. Furthermore, others have argued that the concept of value is broader than instrumental, relational, and intrinsic values; for example, Kenter et al. (2015) define shared and social values to include: communal and cultural values, group values, deliberated values, other-regarding values, value to society and transcendental values. The purpose of this paper is not enter into this debate for, or against, NCP over ecosystem services terminology; but rather to demonstrate whether the inclusion of socio-cultural valuation and ILK within ecosystem service assessments is an improvement over previous global assessments, such as MEA (2005) and TEEB (2010).

\section{Methods}

The IPBES European and Central Asia (ECA) assessment (IPBES 2018c; Martín-López et al. 2018) is one of the four region ecosystem assessments undertaken by IPBES, produced in response to a request from 130 IPBES-member governments. The ECA assessment aimed to demonstrate the importance of nature and associated NCP in the ECA region. In this paper, we review evidence from economic (monetary) and socio-cultural valuation methods of the instrumental and relational values of NCP within the region. Data for the assessment of these values were collated through literature searches of existing value evidence published over the last decade or so: the authors of this paper undertook this evaluation. An aspiration of the IPBES ECA report was to collate this value evidence using a scientifically robust and repeatable approach. Although this was largely achieved, the diversity of values and NCP 
investigated meant that different approaches and data sources were required to capture the different value types.

\section{Market-based monetary valuation of NCP}

Traditional market-based monetary approaches were used to evidence the instrumental values for material NCP. These market data included the mean per Ha profits gained from alternative land uses. Agricultural data were sourced from the Farm Accountancy Data Network (2017), while forestry data were sourced from Eurostat (2016). The values attained were converted to a standardised, International \$ (2017) value to allow direct comparison of values. The standardisation procedure involved.

- If the value currency was not in the local currency, the value was converted to local currency using the appropriate purchasing power parity (PPP) exchange rates. ${ }^{1}$

- This nominal value was then adjusted to real 2017 values using the appropriate national GDP deflators for the chosen base year. ${ }^{2}$

- The real value in local currency was then converted to International \$ (2017) using the relevant purchasing power parity exchange rate.

\section{Non-market monetary valuation of NCP}

Market data were generally not available for regulating and non-material NCP, and hence, evidence of their instrumental value was identified from scientific studies of the non-market, monetary values of these NCP. Three potential valuation databases were initially explored as potential sources of non-market monetary valuation data: the Web of Science (WoS) database of scientific publications, the Environmental Valuation Reference Inventory (EVRI) https ://www.evri.ca/, and the TEEB value database http://www. teebweb.org/publication/tthe-economics-of-ecosystems-andbiodiversity-valuation-database-manual/. We concluded that the EVRI database was the most suitable for the review, since it comprised data that were up to date and in a format that could readily be inputted into our analyses. In contrast,

\footnotetext{
${ }_{1}^{1}$ Purchasing power parity (PPP) exchange rates reflect differences in the cost of living between countries, i.e. it is the exchange rate necessary to allow the purchase of an identical basket of goods in different countries. Data for standardisation of values to 'International \$' were based on the World Bank's World Development Indicators (WDI) dataset: http://databank.worldbank.org/data/views/variableSelection/ selectvariables.aspx ?source $=$ world-development-indicators.

2 GDP deflators are used to take account of the effect of inflation over time. However, inflation rates differ between countries. This fact provides the rationale for converting values into local currency units before applying a deflator.
}

the TEEB database only included data up to 2010, while the WoS would require a significant amount of effort to simply identify relevant studies.

To ensure scientific rigour and repeatability, we utilised a standardised, systematic search protocol to identify and then classify relevant value evidence from the EVRI database. The first step utilised the EVRI's 'Advance search' function of 'study areas' to identify research articles that (1) were based in relevant European and Central Asia countries and (2) were published in English between Jan 2007 and May 2017. Restricting our search to include studies that were published within this period ensured that we only draw on contemporary values, as well as providing an update on the value evidence not included in the TEEB (2010) report. This step identified 496 valuation studies. However, not all of these studies had monetary values presented in an appropriate format suitable for inclusion in the IPBES ECA value review. The search results were thus further refined to only include studies that met the following criteria.

- Articles that were based on primary studies.

- Articles that had value data directly related to ECA countries.

- Articles that had value data directly related to a regulating, material or non-material NCP.

- Articles that had values expressed as a marginal change in the provision of NCP.

- Articles where it was possible to express value evidence in terms of values/ha/year or values/person/year.

This refinement step reduced the number of articles for inclusion in the review to 238 . These articles were then reviewed in detail to extract relevant information, including data on the values, the country, and the NCP. The 238 studies provided a total of 422 value points (i.e., individual value estimates). We then standardised these values to a common currency and base year (International \$2017), as described in "Market-based monetary valuation of NCP". Using SPSS, we then estimated median and mean values 'per Ha per year' and/or median and mean values 'per person per year' for the different NCP and across the four different ECA regions (Western Europe, Central Europe, Eastern Europe, and Central Asia).

\section{Socio-cultural valuation of NCP}

Socio-cultural valuation approaches were reviewed to elicit both relational and instrumental values of NCP. Evidence for this review included scientific studies that utilised sociocultural valuation methods, as well as sources of indigenous and local knowledge (ILK).

For the evidence based on scientific knowledge, we conducted a comprehensive review of relevant literature from 
the Web of Science (WoS) database. The database was queried using a search string comprising three elements: (1) non-monetary valuation indicators (e.g., preference ranking and ratings, perceptions, and/or other non-economic values); (2) geographical range, including the countries of the four ECA sub-regions; and (3) ecosystem services and NCP terms (e.g., ecosystem service and ecosystem benefit) (see Supplementary Material A). The search was applied to the Abstract, Title, and Keywords of English language peer-reviewed scientific articles published between 2007 and 2017. The articles were then screened to ensure that they reported on empirical valuation exercises that elicit values of NCP using non-monetary indicators: articles that focused on conceptual or theoretical issues were excluded from our review. The final screening returned a set of 35 papers, published between 2009 and 2017, that included value evidence from the Western and Central Europe sub-regions: no articles fulfilled our selection criteria in East Europe or Central Asia. Supplementary Material B presents the complete list of papers included in the review. The low number of papers on socio-cultural valuation is consistent with other reviews that also demonstrate that this type of valuation is less applied than economic valuation in ecosystem services research (Christie et al. 2012; Liquete et al. 2013; NietoRomero et al. 2014; Luederitz et al. 2015; Martín-López et al. 2019).

A diverse range of socio-cultural valuation tools were used in the selected articles: i.e., interviews (e.g., Plieninger et al. 2013; Karrasch et al. 2014; Haida et al. 2015), questionnaires (e.g., Castro et al. 2011; Iniesta-Arandia et al. 2014) public participatory GIS (Brown et al. 2015), or roleplaying games (Lamarque et al. 2014). This diversity meant that the values of NCP were elicited using both qualitative and/or quantitative indicators: this diversity made direct comparison of values difficult. In addition, these valuation tools often evaluated more than one NCP. For these studies, we recorded those NCP that were elicited amongst the five most valued by social actors in each case study to enable easier comparison with studies which focussed on one NCP.
To assess ILK values of NCP, we conducted content analysis of the UNESCO document that resulted from the Europe and Central Asia Dialogue Workshop in Paris (11th-13th January 2016), and the follow-up discussions with the selected ILK holders, ILK experts, and experts on ILK (Roue and Molnar 2017). Our analysis used the MAXQDA computer programme to analyse the narratives from herders, farmers, and foresters to provide a qualitative assessment of NCP values.

Further detail of the approaches used to collate evidence for the valuation of NCP in the ECA assessment can be found Martín-López et al. (2018).

\section{Results: the value of NCP in Europe and Central Asia}

The IPBES ECA assessment utilised a range of monetary and socio-cultural approaches to evidence instrumental and relational values of NCP in Europe and Central Asia. Below, we report the findings from this assessment. Where possible, we disaggregate the value evidence across four sub-regions of ECA as this was a key aim of the ECA assessment.

\section{Market-based monetary valuation of NCP}

Market-based monetary values were used to evidence the instrumental value of material NCP (Table 1). Net profits from agricultural production (across EU28 countries) range from $\$ 233 / \mathrm{Ha} /$ year (cereals) to $\$ 916 / \mathrm{Ha} /$ year (mix crop), while the annual gross value added from wood supply in forests was $\$ 255 / \mathrm{Ha} /$ year. We note here that these profit values per Ha are likely to be an over estimate of the value of these material NCP given that many agricultural products receive production grants.

\section{Non-market monetary valuation of NCP}

Non-market monetary valuations methods were used to evidence the instrumental values of material, regulating
Table 1 Market-based monetary valuation of material NCP in Europe and Central Asia

\begin{tabular}{|c|c|c|c|c|}
\hline Land use & Measure & $\begin{array}{l}\text { Mean \$(2017)/ } \\
\text { Ha }\end{array}$ & $\begin{array}{l}\text { Min } \\
\$(2017) / \mathrm{Ha}\end{array}$ & $\begin{array}{l}\operatorname{Max} \\
\$(2017) / \mathrm{Ha}\end{array}$ \\
\hline Cereals ${ }^{1}$ & Net profit & 233 & 5 & 759 \\
\hline Dairy ${ }^{1}$ & Net profit & 718 & 14 & 6443 \\
\hline Mixed crop ${ }^{1}$ & Net profit & 916 & 243 & 2870 \\
\hline Sheep and Goats ${ }^{1}$ & Net profit & 434 & 79 & 8438 \\
\hline Specialist cattle $^{1}$ & Net profit & 381 & 55 & 1320 \\
\hline Forestry (wood supply) ${ }^{2}$ & Gross value added & 255 & 14 & 891 \\
\hline
\end{tabular}

${ }^{1}$ Source: (Farm Accountancy Data Network 2017)

${ }^{2}$ Source: (EUROSTAT 2016) 


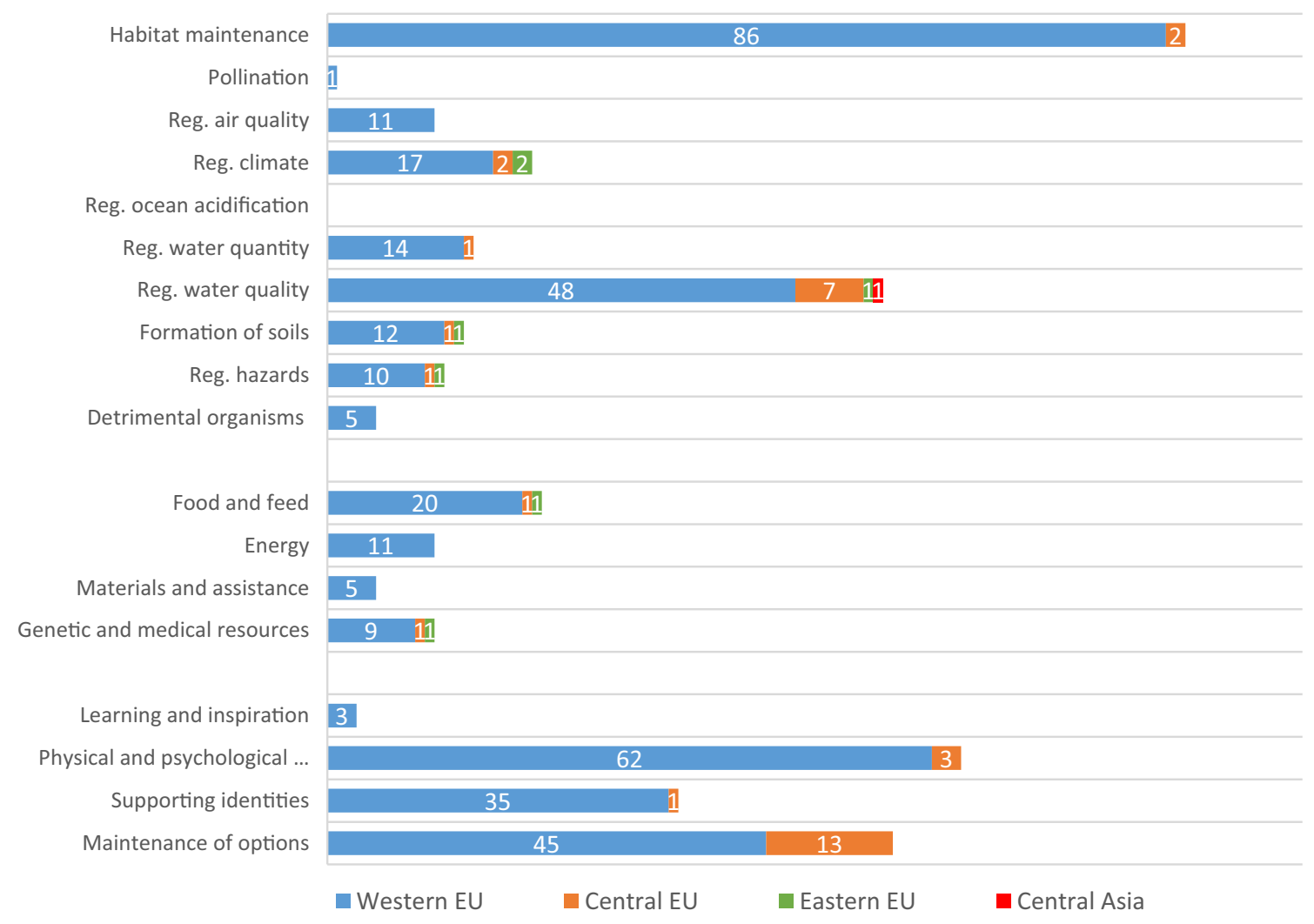

Fig. 3 Number of value points found for each NCP by Europe and Central Asia region

and non-material NCP. Of the 422 value points identified in search of the EVRI database: see Supplementary material 3 for a list of the valuation studies and their associated value data. $92.6 \%(N=391)$ were from studies of Western Europe, $6.4 \%(N=27)$ from Central Europe, $0.1 \%(N=4)$ from Eastern Europe, and only one value point in Central Asia (Fig. 3). Thus, there are significant variations in data availability across the ECA region. The NCP with the greatest number of value points included: Habitat maintenance 20.8\% ( $N=88)$, physical and psychological experience $15.4 \%(N=65)$, maintenance of options $13.7 \%(N=58)$, and regulation of freshwater and coastal water quality $13.6 \%$ $(N=57)$.

Across all ECA countries, regulating NCP were generally the most highly valued by people for their non-market benefits (Table 2): regulation of organism detrimental to humans [median value $=(2017$ Int $\$ 150 /$ person/year $)$ ], regulation of air quality (2017 Int \$127/person/year), and regulation of hazardous and extreme events (2017 Int \$112/person/year). Material and non-material NCP tended to have lower nonmarket values (ranging from Int \$79/person/year for Maintenance of options down to Int $\$ 14 /$ person/year for physical and psychological experience); the exception being material and assistance (2017 Int \$171/person/year).
Analysis also explored non-market values on a per Ha basis (Table 2); although less data were available on these. Again, the highest values were found for regulating NCP: regulation of freshwater and coastal water quality (2017 Int $\$ 1965 / \mathrm{Ha} /$ year) and habitat creation and maintenance (2017 Int $\$ 765 / \mathrm{Ha} /$ year). Non-material NCP, such as Physical and psychological experiences were also highly valued (2017 Int $\$ 1117 / \mathrm{Ha} /$ year).

Above, we report the median values for NCP (Table 2). However, we note that there was a wide range in the nonmarket values, which reflects differences in both the scope and scale of the NCP evaluated. We, therefore, advise caution with respect to directly transferring the reported values to other policy contexts.

\section{Socio-cultural valuation of NCP}

Scientific studies reporting instrumental and relational values of NCP in Western Europe and Central Europe show that non-material NCP were considered the most important by people. Fifty-one per cent of the research papers found non-material NCP among the five most valued by people in socio-cultural terms, while regulating NCP were found in $31 \%$ and material NCP in $18 \%$ of papers. Physical and psychological experiences were found among the 
Table 2 Non-monetary valuation of material, regulating and non-material NCP in Europe and Central Asia

\begin{tabular}{|c|c|c|c|c|c|c|c|c|c|c|}
\hline \multirow[t]{2}{*}{ All ECA } & \multicolumn{5}{|c|}{$\begin{array}{l}\text { Values per person of NCPs in ECA } \\
\text { (2017 Int \$/person/year) }\end{array}$} & \multicolumn{5}{|c|}{$\begin{array}{l}\text { Values per Ha of NCPs in ECA } \\
\text { (2017 Int \$/person/year) }\end{array}$} \\
\hline & Mean & Median & Min & Max & $N$ & Mean & Median & Min & Max & $N$ \\
\hline \multicolumn{11}{|l|}{ Regulating } \\
\hline Habitat creation and maintenance & 114 & 41 & 2 & 914 & 59 & 1387 & 766 & 0.23 & 15,955 & 22 \\
\hline Pollination and dispersal of seeds and other propagules & 53 & 53 & 53.23 & 53 & 1 & - & - & - & - & 0 \\
\hline Regulation of air quality & 113 & 127 & 30 & 190 & 9 & 289 & 289 & 289 & 289 & 1 \\
\hline Regulation of climate & 105 & 26 & 1 & 420 & 12 & 465 & 465 & 62 & 867 & 2 \\
\hline Regulation of ocean acidification & - & & - & - & 0 & & & & & 0 \\
\hline Regulation of freshwater quantity, location and timing & 151 & 46 & 1 & 528 & 8 & 27 & 31 & 10 & 40 & 3 \\
\hline Regulation of freshwater and coastal water quality & 104 & 66 & 1 & 938 & 51 & 3203 & 1965 & 1547 & 6096 & 3 \\
\hline Formation, protection and decontamination of soils and sediments & 12 & 4 & 1 & 48 & 9 & 32 & 32 & 5 & 60 & 2 \\
\hline Regulation of hazards and extreme events & 122 & 112 & 15 & 305 & 8 & - & - & - & - & 0 \\
\hline Regulation of organisms detrimental to humans & 144 & 150 & 1 & 282 & 3 & - & - & - & - & 0 \\
\hline \multicolumn{11}{|l|}{ Material } \\
\hline Energy & 165 & 75 & 1 & 614 & 10 & - & - & - & - & 0 \\
\hline Food and feed & 63 & 21 & 1 & 327 & 15 & 113 & 10 & 2 & 327 & 3 \\
\hline Materials and assistance & 280 & 171 & 1 & 777 & 4 & 1 & 1 & 1 & 1 & 1 \\
\hline Medicinal, biochemical and genetic resources & 138 & 34 & 4 & 845 & 11 & - & - & - & - & 0 \\
\hline \multicolumn{11}{|l|}{ Non-material } \\
\hline Learning and inspiration & 43 & 43 & 43 & 43 & 1 & 7 & 7 & 4 & 10 & 2 \\
\hline Physical and psychological experience & 111 & 14 & 1 & 1315 & 51 & 1473 & 1117 & 22 & 3768 & 6 \\
\hline Supporting identities & 127 & 53 & 1 & 1400 & 32 & 684 & 659 & 1 & 1393 & 3 \\
\hline Maintenance of options & 110 & 79 & 4 & 960 & 53 & 1 & 1 & 1 & 1 & 2 \\
\hline
\end{tabular}

five most valued NCP in $80 \%$ of papers $(N=28)$, whereas Supporting identities was found in $63 \%$ of papers $(N=22)$. Food and feed, a material NCP, is also highly valued in socio-cultural terms (Fig. 4), being found among the five most important NCP in $46 \%$ of papers $(N=16)$. Among regulating NCP, Habitat maintenance and Regulation of freshwater quantity and quality were found to be the most important in socio-cultural terms: both NCP were found among the five most valued NCP in $31 \%$ of the papers ( $N=11$, respectively) (Fig. 4).

Content analysis of the narratives from selected ILK holders showed that nature is mostly valued through its contributions to non-material NCP, particularly Learning and inspiration, Physical and psychological experiences and Supporting identities (Table 3). Quotes from this analysis also show that ILK holders emphasized the importance of non-material NCP through their relational values that contribute to desirable relationships with nature. For example, ILK holders stated the relevance of their attachment to a particular place (which is considered part of the NCP of Supporting identities) for realizing the NCP of learning and the physical experience of recreation:
'We have the knowledge, how the land looks like, where the reindeer go. Now that I've been in this land for so long, it's much easier for me to manage reindeer in this area, compared to someone else who has never been here.' (Reindeer herder)

The narratives of ILK holders also illustrated that the NCP of Supporting identities can be relevant for people in terms of the satisfaction derived from knowing that a particular landscape or species exists and in terms of the opportunities provided by nature to develop a sense of place, belonging, connectedness or sacredness (Table 3). In all of these cases, ILK holders elicited relational values:

'This is like home, you can't tell it. It has to be felt' (Herder)

'I lived in a farmstead since I was a kid, livestock and nature for me are one and the same.' (Herder)

Narratives of ILK holders also showed the importance of material NCP, particularly in terms of Food and feed and Materials and assistance (Table 3), highlighting their instrumental values. Yet, the narratives also showed that these material NCP were relevant for the ILK holders because their resilience and diversity of options: 


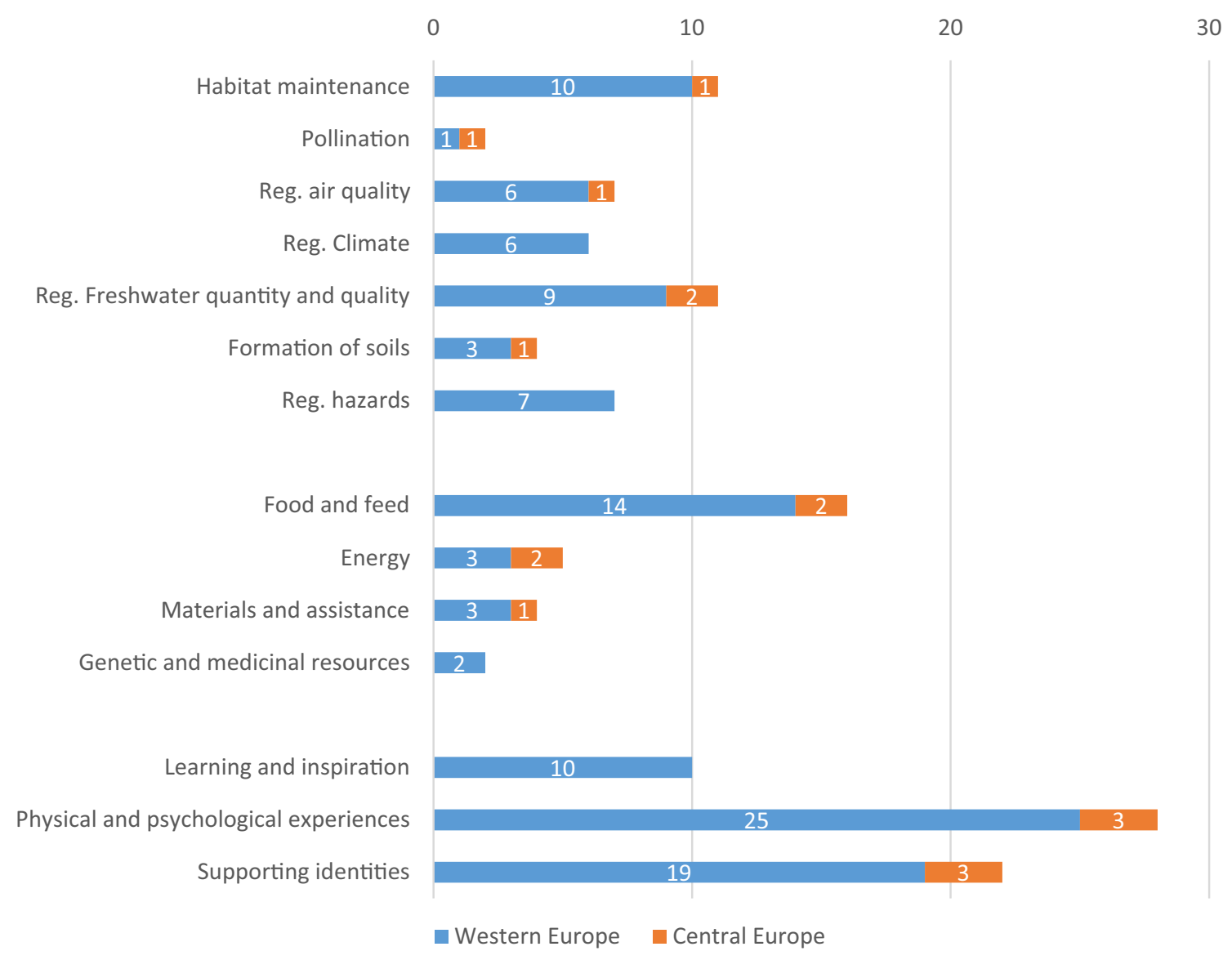

Fig. 4 Number of publications that found each NCP among the five most valued by people in Western and Central Europe (no data were found for East Europe and Central Asia)

'[Arboreal lichen] is a fantastic food for reindeer under catastrophic grazing conditions. There is no such feedstuff to buy with money. Even for money I don't think we would accept that they cut a forest full of arboreal lichen. There is no forage to place on level with arboreal lichen.' (Reindeer herder)

Furthermore, ILK holders highlighted the value of many regulating NCP, such as Habitat maintenance, Regulation of freshwater, Formation of soils, Regulation of hazards, and Regulation of organisms detrimental to humans through the removal of animal carcasses (Table 3). Most of the regulating NCP were valued because of their instrumental and relational values (Table 3). For example, the NCP of Regulation of organisms detrimental to humans was valued by ILK holders because of its instrumental value (i.e., the scavenging benefit), but it also encompassed relational values expressed in spiritual terms: 'Even beasts are made by God and have a purpose, even the bad ones like wolves, they have their own role, they eat the corpses of dead animals, and they cleanse the landscape.' (Herder).

\section{Discussion}

\section{What evidence exists on the instrumental and relational values of values of NCP in Europe and Central Asia?}

The first objective of this paper was to assess evidence on different types of values of NCP in Europe and Central Asia. Data for this analysis was drawn from searches of the scientific literature, along with analyses of ILK dialogue.

Consistent with the previous global assessments (Costanza et al. 1997; TEEB 2010; de Groot et al. 2012; Costanza et al. 2014), our analysis identified significant evidence of the instrumental values of ecosystem services/ NCP. These instrumental values were identified through both market ("Market-based monetary valuation of NCP") and non-market ("Non-market monetary valuation of NCP") monetary techniques, and to a lesser extent through sociocultural methods ("Socio-cultural valuation of NCP"). The prominence of monetary values largely reflects the fact that monetary methods have been extensively used in the region to value ecosystem services/NCP in instrumental terms. It 
Table 3 Selected list of quotes derived from a content analysis of the ILK dialogue in Europe and Central Asia (Roue and Molnar 2017) that show the value of particular NCP

\begin{tabular}{|c|c|c|}
\hline & $\mathrm{NCP}$ & Selected quotes that elicited the value of NCP through ILK \\
\hline \multirow[t]{5}{*}{ Regulating } & Habitat maintenance & $\begin{array}{l}\text { 'The best forest is the one in which one can find all kinds of trees' (Local forester) } \\
\text { 'The game has to hide somewhere' (Local forester and user) } \\
\text { 'Well yes, the owl also needs a place for hiding' (Local foresters) } \\
\text { We need all the forest types, but nowadays the big thing that is missing for us are the old pine } \\
\text { forests that has almost disappeared because of forestry.' (Reindeer herder) }\end{array}$ \\
\hline & $\begin{array}{l}\text { Regulation of freshwater } \\
\text { quantity }\end{array}$ & $\begin{array}{l}\text { 'Maybe it starts to snow in mid-November, so we get } 10-20 \mathrm{~cm} \text { of snow. Then comes a thaw } \\
\text { weather that melts the snow cover so there's only water left. In the meantime, the ground has } \\
\text { frozen by the end of October. So the ground doesn't let through the water anymore: it pools } \\
\text { on the ground instead, especially in dry, lichen-rich pine forests. And soon it's icing [on top of } \\
\text { the lichen]. It can be better where you have thicker humus where the ground lets through the } \\
\text { water.' (Reindeer herder) }\end{array}$ \\
\hline & Formation of soils & $\begin{array}{l}\text { 'Where the animals are roaming around, there is no decay, because the soil had a breath.' (Local } \\
\text { forester) }\end{array}$ \\
\hline & Regulation of hazards & $\begin{array}{l}\text { '[All the forests] are important depending on the conditions. Some may have a shelter effect, } \\
\text { for the wind that will harden the snow in the lichen-rich forest. This spruce forest, that has no } \\
\text { lichen, has the function of stopping the wind.' (Reindeer herder) }\end{array}$ \\
\hline & $\begin{array}{l}\text { Regulation of organisms detri- } \\
\text { mental to humans }\end{array}$ & $\begin{array}{l}\text { 'Even beasts are made by God and have a purpose, even the bad ones like wolves, they have } \\
\text { their own role, they eat the corpses of dead animals, and they cleanse the landscape.' (Herder) }\end{array}$ \\
\hline \multirow[t]{3}{*}{ Material } & Energy & $\begin{array}{l}\text { 'There is need to have firewood, and something to build from (...) For firewood we went only } \\
\text { here, on the Lapos. That was the closest, and there was thin, dry wood, which could be broken } \\
\text { by hand.' (Local forester) }\end{array}$ \\
\hline & Food and feed & $\begin{array}{l}\text { 'There are many types of mushrooms here.' (Local forester) } \\
\text { 'Acorns we could collect. That we could always. The pigs fatten on it.' (Local forester) } \\
\text { '[Arboreal lichen] is a fantastic food for reindeer under catastrophic grazing conditions. There is } \\
\text { no such feedstuff to buy with money. Even for money I don't think we would accept that they } \\
\text { cut a forest full of arboreal lichen. There is no forage to place on level with arboreal lichen.' } \\
\text { (Reindeer herder) }\end{array}$ \\
\hline & Materials and assistance & $\begin{array}{l}\text { 'People used to collect dry twigs with carts. They put them in piles. They had to put it in } \\
\text { between four poles. They put it on the cart in this way and took it away.' (Local forester) } \\
\text { 'The "vassafa" (Cornus sanguinea) is the best skewer for bacon frying. It is firm enough.' (Local } \\
\text { forester) } \\
\text { '...the bark of the elm is a very good tying material. With this we tie up the dry wood on our } \\
\text { back or on the bicycle.' (Local forester) } \\
\text { 'Sure beasts are a problem here, but for this problem you have dogs, you take some men with } \\
\text { you, and you are safe from them.' (Farmer) } \\
\text { 'No, the beasts are no real problem for us, we have our dogs and sticks, we are not afraid of } \\
\text { wolves and bears.' (Herder) }\end{array}$ \\
\hline \multirow[t]{2}{*}{ Non-material } & Learning and inspiration & $\begin{array}{l}\text { 'I was there with the herd, to fatten them, that's why we can explain so much. (...) I only know } \\
\text { what I lived through, I got wet and was cold many times. Several herders explicitly said that } \\
\text { a good herder must learn directly from the animals: We were talking with them like I do with } \\
\text { you now.' (Herder) } \\
\text { 'We have the knowledge, how the land looks like, where the reindeer go. Now that I've been } \\
\text { in this land for so long, it's much easier for me to manage reindeer in this area, compared to } \\
\text { someone else who has never been here.' (Reindeer herder) } \\
\text { 'My grandfather was also forester in the Salánki (the Salánki forest). And my father here. And } \\
\text { we were together all day long with that other forester' (Local foresters) } \\
\text { 'I was born into it. I learnt everything I know about herding from my father, and I adopted what } \\
\text { I needed from the older people.'/'I learnt it from my father. I didn't study this, I inherited it, I } \\
\text { was born into it.' (Herders) }\end{array}$ \\
\hline & $\begin{array}{l}\text { Physical and psychological } \\
\text { experiences }\end{array}$ & $\begin{array}{l}\text { 'I cannot wait for the weekend, just to have a walk in the forest.' (Local forester) } \\
\text { 'If spring comes and the nights are warm enough, we stay out the whole night fishing.' (Local } \\
\text { forester) } \\
\text { 'In springtime when you go out and smell the fresh air, it cannot be told, the feeling of how } \\
\text { wonderful it is.' (Herder) } \\
\text { 'I went bird watching since I was 12. I have always lived close to nature.' (Herder) } \\
\text { 'For me, it's like recreation when I'm out. Nature is like settling for me. I feel good in it, be it } \\
\text { grassland or forest' (Herder) } \\
\text { 'For me, this means relaxation. I have time to watch the wildlife, game and birds.' (Herder) }\end{array}$ \\
\hline
\end{tabular}


Table 3 (continued)

\begin{tabular}{ll}
\hline NCP & Selected quotes that elicited the value of NCP through ILK \\
\hline Supporting identities & 'Then people respected the forest somehow better. Perhaps, because they knew that they were \\
living out of it.' (Local forester) \\
'This is like home, you can't tell it. It has to be felt.' (Herder) \\
'I lived in a farmstead since I was a kid, livestock and nature for me are one and the same.' \\
(Herder) \\
'when the cuckoo sings we are rejoicing as well' (Farmer) \\
'This was the best forest. There was nowhere such a forest. The Masonca, the Borostan and the \\
Hatamsa-köze. There was nowhere such a forest. Nowhither. Large old trees. Who knows how \\
old. Ash, oak, elm. All kinds. Very old trees, now then (Local forester and user) \\
'Everyone knows a proverb saying that 'every seventh [one] is Khidyr.' This proverb reflects \\
folk wisdom that all beings in this world have their representatives with special capacities. For \\
example, we may roughly say that six poplars may be just regular poplars but the seventh one \\
would be 'special', i.e., sacred. And it applies to everything-to trees, springs, animals, and \\
people.' (Guardian of Kochkor-Ata sacred site) \\
'We just borrow the reindeer from our children, and grandchildren and so on. I manage them just \\
for the future, and the same with nature.' (Reindeer herder)
\end{tabular}

is thus important to stress that monetary valuation of NCP still remains core to the IPBES framework (IPBES 2018c).

In contrast, we only found limited evidence of relational values. These relational values were elicited using sociocultural methods and through examination of evidence from ILK communities ("Socio-cultural valuation of NCP"). The limited amount of evidence of relational values partly reflects the fact that relational values are a relatively new concept (see Chan et al. 2016); but it can also reflect the fact that relational values, such as sense of identity, belonging and spirituality were relegated to marginal positions in ecosystem services valuation (Daniel et al. 2012; Chan et al. 2012).

The findings from our searches highlight some of the challenges facing large scale assessments of biodiversity and ecosystems when seeking evidence on NCP values. It was evident from these searches that within the ECA region, there is a significant concentration of evidence from Western Europe; with very little evidence available in Eastern Europe and Central Asia (Figs. 3, 4). Predominantly, this reflects the greater volume of research that is undertaken in Western Europe. However, we also recognise that our searches for evidence were largely restricted to articles published in the English language, and therefore, there may be evidence in other languages that were not picked up in our review. There is also variability in the amount of evidence available on the different NCP, with good volumes of evidence on Physical and psychological experiences and Regulation of freshwater and coastal water quality, but little evidence on Regulation of ocean acidification, Regulation of hazards and Regulation of detrimental organisms (Figs. 3, 4). It is also important to highlight that different search criteria were used to identify the different types of values and for different NCP. This was considered necessary to ensure relevant data was collected in an efficient manner.
Given the above, we argue that the ECA assessment does capture instrumental values of NCP across Europe and Central Asia; however, there still exist significant evidence gaps for certain NCP and for Eastern Europe and Central Asia. Looking wider afield across the other IPBES regional assessments (IPBES 2018a, b, d), it is clear that Western Europe (along with North America: IPBES 2018d) has relatively high levels of evidence, compared to the rest of the world. These observations further highlight potential issues relating to how the approach to searching for evidence may 'privilege' some sources of value evidence over other sources, such as ILK. The ECA (and the other IPBES regional assessments) thus highlights that while it may be desirable to be more inclusive of the diverse values of NCP, there are limitations to the availability of this evidence. Further research is thus required to fill these evidence gaps.

\section{What additional insights into the value of NCP are gained through the inclusion of socio-cultural valuations and ILK?}

Global assessments, such as TEEB (2010), have largely focused on the monetary valuation to assess instrumental values of ecosystem services/NCP. In recent years, the academic and policy communities have highlighted the need to consider a wider range of values, valuation and world views (Kenter et al. 2015; Costanza et al. 2017; Arias-Arevalo et al. 2018). In the IPBES ECA assessment, we address this demand by explicitly considering socio-cultural valuation methods and ILK systems ("Socio-cultural valuation of NCP"). Below, we discuss what additional insights that evidence from these methods bring to ecosystem assessments.

Through the analyses of socio-cultural methods and ILK narratives, our research identified evidence of different relational values, such as sense of place, identity, symbolic 
values and sacredness, recreational and aesthetic values and cognitive development (IPBES 2015; Arias-Arevalo et al. 2018), as well as instrumental values (Table 3 ). This result is consistent with Arias-Arévalo et al. (2017), who found that the analysis of narratives from urban and rural people in the Otún River watershed (Colombia) provided evidence about the multiple relational values (e.g., health, altruism towards others, aesthetic values or cultural heritage) and instrumental values of NCP.

The consideration of ILK has also led to the consideration of NCP not normally addressed in ecosystem assessments. For example, in the ILK dialogues in Europe and Central Asia, the herders highlighted the role of wolves for carrion removal (Regulation of organisms detrimental to humans), as well as the role of guard dogs to protect livestock from wolves (Material and assistance) (Table 3). These two NCP are not recognised in the list of services found in other assessments such as the Millennium Ecosystem Assessment (2005), TEEB (2010), and the Common International Classifications of Ecosystem Services (https://cices.eu/). The inclusion of these two NCP in the IPBES framework enhances previous classifications of ecosystem services by helping to give a 'voice' to the ILK holders such as farmers and herders (Morales-Reyes et al. 2018a, b).

The consideration of socio-cultural methods and ILK in the valuation of NCP may also uncover wider conceptualisations of values including shared social values such as deliberated and other-regarding values (in the sense of Kenter et al. 2015). For example, the importance of the NCP of carrion removal emphasized by herders is expressed as a collective and often refers to its importance for other herders and farmers (other-regarding). Previous research has also found that the relevance of other-regarding values of NCP can be elicited through socio-cultural valuation methods. For example, Oteros-Rozas et al. (2014) found differences between self-regarding and other-regarding altruistic values of ecosystem services provided by transhumance practice.

Evidence from socio-cultural methods and ILK knowledge systems also help to support the move by IPBES to replace supporting, provisioning, regulating and cultural services (Millennium Ecosystem Assessment 2005; TEEB 2010) to a more fluid framing of material, regulating and non-material NCP (IPBES 2018c). Within IPBES, this change symbolises the recognition that NCP do not necessarily fit into discrete categories, but rather there may be some grading across NCP categories (as illustrated in Fig. 2). For example, evidence from the ECA assessment suggest that some non-material recreational activities (such as hunting, fishing and angling, mushroom gathering, berry, and fruit picking) can also be considered as material (wild food) NCP (García-Nieto et al. 2013). In addition, gathering wild edible plants was also highly connected with other nonmaterial NCP, such as Learning and Supporting identities through enhancing sense of belonging [e.g., (Pieroni et al. 2002, 2014; Pardo De Santayana et al. 2005, 2007)]. These examples illustrate how the IPBES framework and the use of socio-cultural methods and ILK can provide the required flexibility and evidence to take account of how different societies value NCP.

Based on the above evidence, we argue that the inclusion of socio-cultural methods and ILK within the IPBES ECA assessment provides a more holistic evidence base than the previous ecosystem services frameworks such as TEEB (2010). This conclusion is also supported in the Americas (IPBES 2018d) and Africa (IPBES 2018a) IPBES regional assessments. These reports note that economic approaches to valuing ecosystem services (which were developed, and, therefore, more suited, to valuing ecosystem services in western societies: Christie et al. 2012) are often inappropriate for valuing NCP in some global south countries. Indeed, global south governments were strong advocates for including socio-cultural methods and ILK to assess "nature's gifts" as a distinct component of NCP (Díaz-Reviriego et al. 2019).

Given that the inclusion of socio-cultural methods and ILK can lead to a wider range of values being considered within ecosystem assessments, the next question then is how to best integrate these diverse values into policy decisions. Unfortunately, the ECA assessment does not provide concrete proposals on how this might best be achieved (IPBES 2018c). Instead, the ECA assessment highlights various ongoing challenges for value integration, including: incommensurable values (i.e., values that cannot be reduced to a common measure); how to weight or trade-off values based on different methodological or epistemological assumptions; how to aggregate diverse values; and how to incorporate a range of value indicators into policy decisions. Furthermore, Löfmarck and Lidskog (2017) also note that IPBES avoids contested and conflict-laden issues, including ontological disagreements on what counts as valid knowledge when working across knowledge systems. Although IPBES does not explicitly address these challenges, we make the following qualified observations. First, although some values may not be readily combined into a common indicator (i.e., are incommensurable), they may still be compatible. For example, narratives from stakeholders could be presented along with economic values to provide a suite of value evidence for, or against, a particular policy option. Second, value integration may need to be considered as a social process that involves conflict resolutions strategies. For example, Cerreta and Panaro (2017) advocate the use of multi-stakeholder spatial decision analysis, while Kenter et al. (2016) demonstrates how deliberative valuation may be used to capture a wide range of values and then discuss how these values may be better embedded in decision-making processes. Kronenberg and Andersson (2019) further demonstrate that even if full value integration is not possible, parallel use of different 
valuation methods produces a more comprehensive picture that using any method alone.

Drawing on the findings highlighted in this paper and others published in this special issue of Sustainability Science, we conclude, as have other researchers cited below, that to address fully the diversity of values future IPBES and other international assessments will need to more explicitly consider gradients in terms of: the type of representation sought from political to statistical (Raymond et al. 2014); the scale of the provider from the individual to that of a culture or community (van Riper et al. 2018); the scale of application of value from the neighbourhood to the global scale (Ives et al. 2018); and the temporal stability of values from stable or minimal change (Manfredo et al. 2017) through to high change (Ives and Fischer 2017). Capturing evidence of NCP values across all these gradients is likely to be challenging and is perhaps a practical limitation of multiple evidence base approaches (Tengö et al. 2014) to valuation in ecosystem assessments. Furthermore, as our example of IPBES ECA assessment suggests, it is often difficult to effectively integrate the different evidence sources. Further research is thus required to explore approaches to the holistic and transparent identification, selection, and integration of multiple values for inclusion in assessments of NCP. Tengö et al. (2014) provide some useful observations for how IPBEStype assessments could better integrate the multiple evidence sources of NCP values.

\section{Concluding comments}

The IPBES conceptual framework was developed as part of an Intergovernmental Science-Policy Platform to generate scientifically robust information to improve the evidence base for better decision-making to protect and enhance the World's biodiversity and associated NCP. To address this evidence need, IPBES developed a conceptual framework that centred around the concept of Nature's contributions to people (NCP); where NCP embraces both ecosystem services and Nature's gifts. The adoption of the term and conceptual framing of NCP provides a clear statement that IPBES is aiming to extend the ecosystem services concept by accounting for a wider range of values, valuation methods and value providers. As the findings presented in this paper suggest, the NCP paradigm by focusing on instrumental and relational values treats values more holistically than the previous assessments such as the MEA (2005) and TEEB (2010). For example, by giving a 'voice' to ILK holders, we demonstrated new types of NCP such as carrion removal, along with evidence of relational values including sense of place, identity, symbolic values and sacredness. However, the IPBES conceptual framework is not without controversy. In particular, the introduction of the term 'nature's contribution to people' (NCP) has been subject to much debate (Braat 2018; de Groot et al. 2018; Kenter 2018; Peterson et al. 2018). In this paper, we do not enter into arguments as to which terminology (NCP or ecosystem services) is best; but rather focus on demonstrating the additional insights that the inclusion of sociocultural methods and ILK knowledge within assessments can bring in terms of uncovering the diversity of values. Furthermore, we also recognise that much of the research on ecosystem services was already considering socio-cultural valuations (see Supplementary Material B) and that socio-cultural valuation is increasingly used in ecosystem service research (e.g., Martín-López et al. 2019). What is novel about IPBES, is that it is the first international level assessment that explicitly accounts for the diversity of values and valuation methods, as well as providing a 'voice' to a wider range of stakeholders particularly ILK holders.

The IPBES ECA assessment was adopted by 130 countries during the IPBES Plenary held in Medellin, Columbia in March 2018. The IPBES conceptual framework has been applied to three other regional assessments (the Americas, African and Asia and Pacific assessments) (IPBES 2018a, b, d), the global assessment (IPBES 2019), and the assessments on Pollinators, pollination and food production (IPBES 2016a), Scenarios and models of biodiversity and ecosystem services (IPBES 2016b), and Land degradation (IPBES 2018f). Although these assessments have made significant advancements is ecosystem service assessments, IPBES also acknowledges that there are still knowledge gaps and uncertainty in its conceptual framework, particularly in terms of how to best integrate the diversity of values into policy decisions. To address these limitations, IPBES is currently undertaking a 'Methodological assessment regarding the diverse conceptualization of multiple values of nature and its benefits, including biodiversity and ecosystem services' (https://www.ipbes.net/deliverables/3d-values). The objectives of this Values Assessment are to assess: (a) the diverse conceptualization of values of nature and its benefits; (b) the diverse valuation methodologies and approaches; (c) the different approaches that acknowledge, bridge and integrate the diverse values and valuation methodologies for policy and decision-making support; and (d) knowledge and data gaps and uncertainties (IPBES 2018e). This assessment is due to report in 2021.

Acknowledgements This manuscript has benefited from the discussions with Sandra Díaz and Marie Stenseke in Medellín (Colombia) during the 6th IPBES Plenary, and we are also grateful for the comments from Chris Raymond and anonymous referees. Finally, we would also like to thank all the other authors of Chapter 2 of the IPBES ECA (2018c) report, including the two co-chairs of the ECA assessment (Rounsevell, M and Fischer, M), the IPBES Secretariat (Rando, AT-M, and Mader, A), the Lead authors (Başak Dessane, E., Berry, P., Chenu, C., Gerino, M., Keune, H., Osipova, E., Oteros-Rozas, E., Paillard, S., Rossberg, A. G., Schröter, M. and van Oudenhoven, A. 
P. E.), and Contributing authors (Karabulut AA, Çokçalışkan BA, Bilgin A, Breeze T, Bukvareva E, Duez P, Faith DP, Geijzendorffer I, Gosal A, Haider LJ, Kretsch C, Lozano J, Meire P, Meyer M, Moleón M, Morales-Reyes Z, Oosterbroek B, Potts SG, Povilaityte-Petri V, Ruiz Almeida A, Sánchez-Zapata JA, Sievers-Glotzbach S, Sorokin A, Sousa Pinto I, Stange E and Osipova E.).

Open Access This article is distributed under the terms of the Creative Commons Attribution 4.0 International License (http://creativeco mmons.org/licenses/by/4.0/), which permits unrestricted use, distribution, and reproduction in any medium, provided you give appropriate credit to the original author(s) and the source, provide a link to the Creative Commons license, and indicate if changes were made.

\section{References}

Arias-Arevalo P, Martín-López B, Gómez-Baggethun E (2017) Exploring intrinsic, instrumental, and relational values for sustainable management of social-ecological systems. Ecol Soc 22(4):43. https://doi.org/10.5751/ES-09812-220443

Arias-Arevalo P, Gómez-Baggethun E, Martín-López B, PerezRincon M (2018) Widening the evaluative space for ecosystem services: a taxonomy of plural values and valuation methods. Environ Values 27:29-53

Barton DN, Kelemen E, Dick J, Martin-Lopez B, Gómez-Baggethun E, Jacobs S, Hendriks CMA, Termansen M, García-Llorente M, Primmer E, Dunford R, Harrison PA, Turkelboom F, Saarikoski H, van Dijk J, Rusch GM, Palomo I, Yli-Pelkonen VJ, Carvalho L, Baró F, Langemeyer J, van der Wal JT, Mederly P, Priess JA, Luque S, Berry P, Santos R, Odee D, Pastur GM, García Blanco G, Saarela S-R, Silaghi D, Pataki G, Masi F, Vădineanu A, Mukhopadhyay R, Lapola DM (2018) (Dis) integrated valuation-assessing the information gaps in ecosystem service appraisals for governance support. Ecosyst Serv 29:529-541. https://doi.org/10.1016/j.ecoser.2017.10.021

Braat L (2018) Five reasons why the Science publication "Assessing nature's contributions to people" (Díaz et al. 2018) would not have been accepted in Ecosystem Services. Ecosyst Serv 30:A1-A2

Brown G, Hausner VH, Grodzińska-Jurczak M, Pietrzyk-Kaszyńska A, Olszańska A, Peek B, Rechciński M, Lægreid E (2015) Cross-cultural values and management preferences in protected areas of Norway and Poland. J Nat Conserv 28:89-104. https:// doi.org/10.1016/j.jnc.2015.09.006

Castro AJ, Martín-López B, García-LLorente M, Aguilera PA, López E, Cabello J (2011) Social preferences regarding the delivery of ecosystem services in a semiarid Mediterranean region. J Arid Environ 75(11):1201-1208. https://doi.org/10.1016/j.jarid env.2011.05.013

Cerreta M, Panaro S (2017) From perceived values to shared values: a multi-stakeholder spatial decision analysis (M-SSDA) for resilient landscapes. Sustainability 9(7):1113. https://doi. org/10.3390/su9071113

Chan K, Satterfield T, Goldstein J (2012) Rethinking ecosystem services to better address and navigate cultural values. Ecol Econ 74:8-18

Chan KMA, Balvanera P, Benessaiah K, Chapman M, Díaz S, Gómez-Baggethun E, Gould R, Hannahs N, Jax K, Klain S, Luck GW, Martín-López B, Muraca B, Norton B, Ott K, Pascual U, Satterfield T, Tadaki M, Taggart J, Turner N (2016) Opinion: why protect nature? Rethinking values and the environment. Proc Natl Acad Sci 113(6):1462-1465. https://doi.org/10.1073/ pnas. 1525002113
Christie M, Fazey I, Cooper R, Hyde T, Kenter JO (2012) An evaluation of monetary and non-monetary techniques for assessing the importance of biodiversity and ecosystem services to people in countries with developing economies. Ecol Econ 83:67-78

Costanza R, D'Arge R, de Groot R, Farber S, Grasso M, Hannon B, Limburg K, Naeem S, O’Neill RV, Paruelo J, Raskin RG, Sutton $P$, van den Belt M (1997) The value of the world's ecosystem services and natural capital. Nature 387(6630):253-260. https ://doi.org/10.1038/387253a0

Costanza R, de Groot R, Sutton P, van der Ploeg S, Anderson SJ, Kubiszewski I, Farber S, Turner RK (2014) Changes in the global value of ecosystem services. Glob Environ Change 26:152-158. https://doi.org/10.1016/j.gloenvcha.2014.04.002

Costanza R, de Groot R, Braat L, Kubiszewski I, Fioramonti L, Sutton P, Farber S, Grasso M (2017) Twenty years of ecosystem services: how far have we come and how far do we still need to go? Ecosyst Serv 28:1-16

Daniel TC, Muhar A, Arnberger A, Aznar O, Boyd JW, Chan KMA, Costanza R, Elmqvist T, Flint CG, Gobster PH, Grêt-Regamey A, Lave R, Muhar S, Penker M, Ribe RG, Schauppenlehner T, Sikor T, Soloviy I, Spierenburg M, Taczanowska K, Tam J, von der Dunk A (2012) Contributions of cultural services to the ecosystem services agenda. PNAS 109(23):8812-8819. https://doi. org/10.1073/pnas.1114773109

de Groot R, Brander L, van der Ploeg S, Costanza R, Bernard F, Braat L, Christie M, Crossman N, Ghermandi A, Hein L, Hussain S, Kumar P, McVittie A, Portela R, Rodriguez LC, ten Brink P, van Beukering P (2012) Global estimates of the value of ecosystems and their services in monetary units. Ecosyst Serv 1:50-61

de Groot R, Costanza R, Braat L, Brander L, Burkhard B, Carrascosa JL, Crossman N, Egoh B, Geneletti D, Hansjuergens B, Hein L, Jacobs SJ, Kubiszewski I, Leimona B, Li B, Liu J, Luque S, Maes J, Marais C, Maynard S, Montanarella L, Moolenaar S, Obst C, Quintero M, Saito O, Santos-Martín F, Sutton P, van Beukering P, van Weelden M, Willemen L (2018) Ecosystem services are nature's contributions to people: response to: assessing nature's contributions to people. Sci Prog 359(6373)

Díaz S, Demissew S, Joly C, Lonsdale W, Larigauderie A (2015) A Rosetta stone for nature's benefits to people. Plos Biol. https://doi. org/10.1371/journal.pbio.1002040

Díaz S, Pascual U, Stenseke M, Martín-López B, Watson R, Molnar Z, Hill R, Chan K, Baste I, Brauman K, Polasky S, Church A, Lonsdale M, Larigauderie A, Leadley P, van Oudenhoven A, van der Plaat F, Schroter M, Lavorel S, Aumeeruddy-Thomas Y, Bukvareva E, Davies K, Demissew S, Erpul G, Failler P, Guerra C, Hewitt C, Keune H, Lindley S, Shirayama Y (2018) Assessing nature's contributions to people. Science 359:270-272

Díaz-Reviriego I, Turnhout E, Beck S (2019) Participation and inclusiveness in the intergovernmental science-policy platform on biodiversity and ecosystem services. Nat Sustain 2:457-464

Eurostat (2016) Forests, forestry and logging. http://ec.europa.eu/euros tat/statistics-explained/index.php/File:Economic_indicators_for_ forestry_and_logging,_2005_and_2013.png\#file

Farm Accountancy Data Network (2017) http://www.farmbusinesssur vey.co.uk/benchmarking/Default.aspx ?module $=$ FADN

García-Nieto AP, García-LLorente M, Iniesta-Arandia I, Martín-López B (2013) Mapping forest ecosystem services: from providing units to beneficiaries. Ecosyst Serv Elsevier 4(C):126-138

Gómez-Baggethun E, Martín-López B (2015) Ecological economics perspectives on ecosystem service valuation. In: Martinez-alier J, Muradian R (eds) Handbook of ecological economics. Edward Elgar, Cheltenham, pp 260-282

Haida C, Rüdisser J, Tappeiner U (2015) Ecosystem services in mountain regions: experts' perceptions and research intensity. Reg Environ Change 16(7):1989-2004. https://doi.org/10.1007/ s10113-015-0759-4 
Hill R, Nates-Parra G, Quezada-Euán JJG, Buchori D, LeBuhn G, Maués MM, Pert PL, Kwapong PK, Saeed S, Breslow SJ, Carneiro da Cunha M, Dicks LV, Galetto L, Gikungu M, Howlett BG, Imperatriz-Fonseca VL, Lyver PO, Martín-López B, Oteros-Roza E, Potts SG, Roué M (2019) Biocultural approaches to pollinator conservation. Nat Sustain 2:214-222

Iniesta-Arandia I, García-Llorente M, Aguilera PA, Montes C, MartínLópez B (2014) Socio-cultural valuation of ecosystem services: uncovering the links between values, drivers of change, and human well-being. Ecol Econ 108:36-48

IPBES (2015) IPBES/4/INF/1: preliminary guide regarding diverse conceptualization of multiple values of nature and its benefits, including biodiversity and ecosystem functions and services [deliverable 3(d)]. Report of the Fourth Session of the Plenary of the Intergovernmental Science-Policy Platform on Biodiversity and Ecosystem Services

IPBES (2016a) Summary for policymakers of the assessment report of the Intergovernmental Science-Policy Platform on Biodiversity and Ecosystem Services on pollinators, pollination and food production. In: Potts SG, Imperatriz-Fonseca VL, Ngo HT, Biesmeijer JC, Breeze TD, Dicks LV, Garibaldi LA, Hill R, Settele J, Vanbergen AJ, Aizen MA, Cunningham SA, Eardley C, Freitas BM, Gallai N, Kevan PG, Kovács-Hostyánszki A, Kwapong PK, Li J, Li X, Martins DJ, Nates-Parra G, Pettis JS, Rader R, Viana BF (eds) Secretariat of the Intergovernmental Science-Policy Platform on Biodiversity and Ecosystem Services, Bonn, Germany

IPBES (2016b) Summary for policymakers of the methodological assessment of scenarios and models of biodiversity and ecosystem services of the Intergovernmental Science-Policy Platform on Biodiversity and Ecosystem Services. In: Ferrier S, Ninan KN, Leadley P, Alkemade R, Acosta LA, Akçakaya HR, Brotons L, Cheung W, Christensen V, Harhash KA, Kabubo-Mariara J, Lundquist C, Obersteiner M, Pereira H, Peterson G, Pichs-Madruga $\mathrm{R}$, Ravindranath NH, Rondinini C, Wintle B (eds) Secretariat of the Intergovernmental Science-Policy Platform on Biodiversity and Ecosystem Services, Bonn, Germany

IPBES (2018a) Summary for policymakers of the regional assessment report on biodiversity and ecosystem services for Africa of the Intergovernmental Science-Policy Platform on Biodiversity and Ecosystem Services. In: Archer E, Dziba LE, Mulongoy KJ, Maoela MA, Walters M, Biggs R, Cormier-Salem M-C, DeClerck F, Diaw MC, Dunham LAE, Failler P, Gordon C, Halmy MW, Harhash KA, Kasisi R, Kizito F, Mensah A, de T, Morais L, Nyingi WD, Oguge N, Osman-Elasha B, Stringer LC, Assogbadjo A, Egoh BN, Heubach K, Pereira L, Sitas N (eds). IPBES secretariat, Bonn, Germany

IPBES (2018b) Summary for policymakers of the regional assessment report on biodiversity and ecosystem services for Asia and the Pacific of the Intergovernmental Science-Policy Platform on Biodiversity and Ecosystem Services. Karki M, Senaratna Sellamuttu S, Okayasu S, Suzuki W, Acosta L, Alhafedh Y, Anticamara JA, Ausseil AG, Davies K, Gasparatos A, Gundimeda H, Ibrahim FH, Kohsaka R, Kumar R, Managi S, Wu N, Rajvanshi A, Rawat GS, Riordan P, Sharma S, Virk A, Wang C, Yahara T, Youn Y (eds). IPBES Secretariat, Bonn, Germany

IPBES (2018c) Summary for policymakers of the regional assessment report on biodiversity and ecosystem services for Europe and Central Asia of the Intergovernmental Science-Policy Platform on Biodiversity and Ecosystem Services. In: Fischer M, Rounsevell M, Torre-Marin Rando A, Mader A, Church A, Elbakidze M, Elias V, Hahn T, Harrison P, Hauck J, Martín-López B, Ring I, Sandström C, Sousa Pinto I, Visconti P, Zimmermann V, Christie M (eds). IPBES Secretariat, Bonn, Germany

IPBES (2018d) Summary for policymakers of the regional assessment report on biodiversity and ecosystem services for the Americas of the Intergovernmental Science-Policy Platform on Biodiversity and Ecosystem Services. In: Rice J, Seixas CS, Zaccagnini ME, Bedoya-Gaitán M, Valderrama N, Anderson CB, Arroyo MTK, Bustamante M, Cavender-Bares J, D í az-de-León A, Fennessy S, García Marquez JR, García K, Helmer EH, Herrera B, Klatt B, Ometo JP, Rodriguez Osuna V, Scarano FR, Schill S, Farinaci JS (eds). IPBES Secretariat, Bonn, Germany

IPBES (2018e) Scoping for the methodological assessment regarding the diverse conceptualization of multiple values of nature and its benefits, including biodiversity and ecosystem services [deliverable 3 (d)]. Plenary of the Intergovernmental Science-Policy Platform on Biodiversity and Ecosystem Services Sixth session Medellin, Colombia, 18-24 March 2018 IPBES/6/INF/9

IPBES (2018f) Summary for policymakers of the assessment report on land degradation and restoration of the Intergovernmental Science Policy Platform on Biodiversity and Ecosystem Services. In: Scholes R, Montanarella L, Brainich A, Barger N, ten Brink B, Cantele M, Erasmus B, Fisher J, Gardner T, Holland TG, Kohler F, Kotiaho JS, Von Maltitz G, Nangendo G, Pandit R, Parrotta J, Potts MD, Prince S, Sankaran M, Willemen L (eds). IPBES secretariat, Bonn, Germany

IPBES (2019) Global assessment report on biodiversity and ecosystem services of the Intergovernmental Science-Policy Platform on Biodiversity and Ecosystem Services. In: Brondizio ES, Settele J, Díaz S, Ngo HT (eds). IPBES Secretariat, Bonn, Germany

Ives CD, Fischer J (2017) The self-sabotage of conservation: reply to Manfredo et al. Conserv Biol 31(6):1483-1485

Ives CD, Gordon A, Oke C, Raymond CM, Hehir A, Bekessy SA (2018) Spatial scale influences how people value and perceive green open space. J Environ Plan Manage 61(12):2133-2150. https://doi.org/10.1080/09640568.2017.1388219

Jacobs S, Dendoncker N, Martín-López B, Barton D, Gómez-Baggethun E, Boeraeve F, McGrath F, Vierikkoh K, Geneletti D, Sevecke K, Pipart N, Primmer E, Mederly P, Schmidt S, Aragao A, Baral H, Bark R, Briceno T, Brogna D, Cabral P, De Vreese R, Liquete C, Mueller H, Peh K, Phelan A, Rincon A, Rogers S, Turkelboom F, Van Reeth W, van Zanten B, Wam H, Washbourne C (2016) A new valuation school: integrating diverse values of nature in resource and land use decisions. Ecosyst Serv 22:213-220

Jacobs S, Martín-López B, Barton D, Dunford R, Harrison P, Kelemen E, Saarikoski H, Termansen M, García-Llorente M, Gómez-Baggethun E, Kopperoinen L, Luque S, Palomo I, Priess J, Rusch G, Tenerelli P, Turkelboom F, Demeyer R, Hauck J, Keune H, Smith $R$ (2018) The means determine the end-pursuing integrated valuation in practice. Ecosyst Serv 29:515-528

Karrasch L, Klenke T, Woltjer J (2014) Linking the ecosystem services approach to social preferences and needs in integrated coastal land use management-a planning approach. Land Use Policy 38:522-532. https://doi.org/10.1016/j.landusepol.2013.12.010

Kenter JO (2018) IPBES: don't throw out the baby whilst keeping the bathwater; put people's values central, not nature's contributions. Ecosyst Serv 33:40-43. https://doi.org/10.1016/j.ecose r.2018.08.002

Kenter JO, O’Brien L, Hockley N, Ravenscroft N, Fazey I, Irvine KN, Reed MS, Christie M, Brady E, Bryce R, Church A, Cooper N, Davies A, Evely A, Everard M, Fish R, Fisher JA, Jobstvogt N, Molloy C, Orchard-Webb J, Ranger S, Ryan M, Watson V, Williams S (2015) What are shared and social values of ecosystems? Ecol Econ 111:86-99

Kenter JO, Bryce R, Christie M, Cooper N, Hockley N, Irvine KN, Fazey I, O'Brien L, Orchard-Webb J, Ravenscroft N, Raymond CM, Reed MS, Tett P, Watson V (2016) Shared values and deliberative valuation: future directions. Ecosyst Serv 21:358-371

Kirchhoff T (2019) Abandoning the concept of cultural ecosystem services, or against natural-scientific imperialism. BioScience 69(3):220-227. https://doi.org/10.1093/biosci/biz007 
Kronenberg J, Andersson E (2019) Integrating social values with other value dimensions: parallel use vs. combination vs. full integration. Sustain Sci. https://doi.org/10.1007/s11625-019-00688-7

Lamarque P, Meyfroidt P, Nettier B, Lavorel S (2014) How ecosystem services knowledge and values influence farmers' decisionmaking. PLoS One 9(9):e107572. https://doi.org/10.1371/journ al.pone. 0107572

Liquete C, Piroddi C, Drakou EG, Gurney L, Katsanevakis S, Charef A et al (2013) Current status and future prospects for the assessment of marine and coastal ecosystem services: a systematic review. PLoS One. https://doi.org/10.1371/journal.pone.0067737

Lofmarck E, Lidskog R (2017) Bumping against the boundary: IPBES and the knowledge divide. Environ Sci Policy 69:22-28

Luederitz C, Brink E, Gralla F, Hermelingmeier V, Meyer M, Niven L et al (2015) A review of urban ecosystem services: six key challenges for future research. Ecosyst Serv 14:98-112. https://doi. org/10.1016/j.ecoser.2015.05.001

Maes J, Burkhard B, Geneletti D (2018) Ecosystem services are inclusive and deliver multiple values. A comment on the concept of nature's contributions to people. One Ecosyst 3:e24720. https:// doi.org/10.3897/oneeco.3.e24720

Manfredo MJ, Bruskotter JT, Teel TL, Fulton D, Schwartz SH, Arlinghaus R, Oishi S, Uskul AK, Redford K, Kitayama S, Sullivan L (2017) Why social values cannot be changed for the sake of conservation. Conserv Biol 31:772-780

Martín-López B, Church A, Başak Dessane E, Berry P, Chenu C, Christie M, Gerino M, Keune H, Osipova E, Oteros-Rozas E, Paillard S, Rossberg AG, Schröter M, van Oudenhoven APE (2018) Nature's contributions to people and quality of life. In: Rounsevell M, Fischer M, Torre-Marin Rando A, Mader A (eds) The IPBES regional assessment report on biodiversity and ecosystem services for Europe and Central Asia. Secretariat of the Intergovernmental Science-Policy Platform on Biodiversity and Ecosystem Services, Bonn

Martín-López B, Leister I, Lorenzo Cruz P, Palomo I, Gret-Regamey A, Harrison PA, Lavorel S, Locatelli B, Luque S, Walz A (2019) Nature's contributions to people in mountains: a review. PLoS One 14(6):e0217847. https://doi.org/10.1371/journal.pone.02178 47

Millennium Ecosystem Assessment (2005) Ecosystems and human well-being: synthesis. A report of the millennium ecosystem assessment. Island Press, Washington

Moon K, Blackman D (2014) A guide to understanding social science research for natural scientists. Conserv Biol 28:1167-1177

Morales-Reyes Z, Martín-López B, Moleon M, Mateo-Tomas P, Botella F, Margalida A, Donazar J, Blanco G, Perez I, Sanchez-Zapata J (2018a) Farmer perceptions of the ecosystem services provided by scavengers: what, who, and to whom. Conserv Lett 11(2):e12392. https://doi.org/10.1111/conl.12392

Morales-Reyes Z, Martín-López B, Moleón M, Mateo-Tomas P, Olea P, Arrondo E, Donázar J, Sánchez-Zapata J (2018b) Shepherds' local knowledge and scientific data on the scavenging ecosystem service: insights for conservation. AMBIO 48(1):48-60. https:// doi.org/10.1007/s13280-018-1055-6

Nieto-Romero M, Oteros-Rozas E, González JA, Martín-López B (2014) Exploring the knowledge landscape of ecosystem services assessments in Mediterranean agroecosystems: insights for future research. Environ Sci Policy 37:121-133. https://doi. org/10.1016/j.envsci.2013.09.003

Oteros-Rozas E, Martín-López B, González JA, Plieninger T, López CA, Montes C (2014) Socio-cultural valuation of ecosystem services in a transhumance social-ecological network. Reg Environ Change 14:1269-1289. https://doi.org/10.1007/s1011 3-013-0571-y
Pardo de Santayana M, Blanco E, Morales R (2005) Plants known as te' in Spain: an ethno-pharmaco-botanical review. J Ethnopharmacol 98(1-2):1-19. https://doi.org/10.1016/j.jep.2004.11.003

Pardo de Santayana M, Tardio J, Blanco E, Carvalho AM, Lastra JJ, San Miguel ES, Morales R (2007) Traditional knowledge of wild edible plants used in the northwest of the Iberian Peninsula (Spain and Portugal): a comparative study. J Ethnobiol Ethnomed 3:27. https://doi.org/10.1186/1746-4269-3-27

Pascual U, Balvanera P, Díaz S, Pataki G, Roth E, Stenseke M, Watson R, Dessane E, Islar M, Kelemen E, Maris V, Quaas M, Subramanian S, Wittmer H, Adlan A, Ahn S, Al-Hafedh Y, Amankwah E, Asah S, Berry P, Bilgin A, Breslow S, Bullock C, Caceres D, Daly-Hassen H, Figueroa E, Golden C, Gómez-Baggethun E, Gonzalez-Jimenez D, Houdet J, Keune H, Kumar R, Ma K, May P, Mead A, O'Farrell P, Pandit R, Pengue W, Pichis-Madruga R, Popa F, Preston S, Pacheco-Balanza D, Saarikoski H, Strassburg B, van den Belt M, Verma M, Wickson F, Yagi N (2017) Valuing nature's contributions to people: the IPBES approach. Curr Opin Environ Sustain 26-27:7-16

Pearce DW, Moran D (1994) The economic value of biodiversity. Routeledge, London

Peterson G, Harmáčková Z, Meacham M, Queiroz C, Jiménez-Aceituno A, Kuiper J, Malmborg K, Sitas N, Bennett E (2018) Welcoming different perspectives in IPBES: "Nature's contributions to people" and 'Ecosystem services'. Ecol Soc 23:art39. https://doi. org/10.5751/es-10134-230139

Pieroni A, Nebel S, Quave C, Münz H, Heinrich M (2002) Ethnopharmacology of liakra: traditional weedy vegetables of the Arbëreshë of the Vulture area in southern Italy. J Ethnopharmacol 81(2):165185. https://doi.org/10.1016/S0378-8741(02)00052-1

Pieroni A, Cianfaglione K, Nedelcheva A, Hajdari A, Mustafa B, Quave CQ (2014) Resilience at the border: traditional botanical knowledge among Macedonians and Albanians living in Gollobordo, Eastern Albania. J Ethnobiol Ethnomed 10:31. https://doi. org/10.1186/1746-4269-10-31

Plieninger T, Dijks S, Oteros-Rozas E, Bieling C (2013) Assessing, mapping and quantifying cultural ecosystem services at community level. Land Use Policy 33:118-129. https://doi.org/10.1016/j. landusepol.2012.12.013

Raymond CM, Kenter JO, Plieninger T, Turner NJ, Alexander KA (2014) Comparing instrumental and deliberative paradigms underpinning the assessment of social values for cultural ecosystem services. Ecol Econ 107:145-156

Roué M, Molnár Z (eds) (2017) Knowing our lands and resources: indigenous and local knowledge of biodiversity and ecosystem services in Europe and Central Asia. Knowledges of Nature 9. UNESCO: Paris

TEEB (2010) The economics of ecosystems and biodiversity: ecological and economic foundations. Routledge, London

Tengö M, Brondizio ES, Elmqvist T, Malmer P, Spierenburg M (2014) Connecting diverse knowledge systems for enhanced ecosystem governance: the multiple evidence base approach. AMBIO 43:579. https://doi.org/10.1007/s13280-014-0501-3

van Riper C, Winkler-Schor S, Stamberger L, Keller R, Braito M, Raymond C, Eriksson M, Golebie E, Johnson D (2018) Test how variation in behavioral patterns was explained by the cultural, individual, and assigned values of survey respondents. Sustain Soc, This Issue

Publisher's Note Springer Nature remains neutral with regard to jurisdictional claims in published maps and institutional affiliations. 